\title{
Response of Barley Seedlings to the Toxicity by Arsenic V
}

\author{
Ana Isabel Mireles-Arriaga ${ }^{1}$, Adriana Saldaña-Robles², Jesús Hernández-Ruiz', \\ Erik Díaz-Cervantes ${ }^{3}$, José Luis Zárate-Castrejón ${ }^{4}$, Jorge Eric Ruiz-Nieto ${ }^{1 *}$
}

${ }^{1}$ Universidad de Guanajuato, Departamento de Agronomía, Irapuato, Guanajuato, México ${ }^{2}$ Universidad de Guanajuato, Departamento de Ingeniería Agrícola, Irapuato, Guanajuato, México

${ }^{3}$ Universidad de Guanajuato, Departamento de Alimentos, Tierra Blanca, Guanajuato, México

${ }^{4}$ Universidad de Guanajuato, División de Ciencias de la Salud e Ingenierías, Celaya, Guanajuato

Received: 17 February 2021

Accepted: 13 April 2021

\begin{abstract}
Due to its geological origin and the intense agro-industrial activity, regions whose vocation is the agri-food production present a high level of contamination by heavy metals as the arsenic that induces toxicity in the crops of economic importance as in the case of barley (Hordeum vulgare L.). The evaluation of the response of different cultivars and genotypes in the first phenological stages is indispensable to generate technical information regard the tolerance to arsenic and the same time theoretical knowledge about how this metal is absorbed. The aim of this study was to evaluate the physiological response of barley seedlings to arsenic $\mathrm{V}(\mathrm{AsV})$ toxicity and deduce how this metal could be absorbed by the plants. Seedlings of the cultivars Alina and Esperanza were evaluated under the concentrations of 100, 200, 500 and $700 \mathrm{mg} \mathrm{L}^{-1}$. Besides, models for the proteins PHT1 and HvHMA1 were performed by homology with affinity assays for AsV. The seedlings of Alina presented higher degree of tolerance to the toxicity whereby potentially the productive plots of this cultivar Alina could tolerate higher concentrations of this heavy metal. Also, the AsV could be transported by its competence with the endogenous ions as $\mathrm{Mg}^{2}+$ and $\mathrm{PO}^{3-}$.
\end{abstract}

Keywords: Hordeum vulgare L., seeds, heavy metal, physiology, protein-modeling

\section{Introduction}

Heavy metals are elements with atomic weights between 63.5 and 200.6, as well as a specific gravity greater than 5.0. The term heavy metal is referred to any metallic chemical element relatively toxic in even low concentrations and of high density [1]; as

*e-mail: jorge.ruiz@ugto.mx in the case of arsenic (As) for plants [2]. The As can be found in the soil as arsenic III (AsIII) or V (AsV), being the second type sixty times more toxic for the plants [3]. In plants, the AsV competes with phosphate and enters the plant cell via inorganic phosphorous transporters [4]. The assimilation of As during the life cycle of the plants growing on polluted soils lead to tissues with high concentrations of the heavy metal [5]. A possible mechanism for the entry of heavy metals into the barley cells is through heavy metal pumps, which are part of the super family of P-type ATPase pumps; 
in this superfamily, the protein HvHMA1 stands out and is present in Hordeum vulgare L. [6]. The AsV is rapidly oxidized to AsIII in the cell, causing stress by cellular oxidation [7]. This stress limits the growth and seed yield due to the affectations on the metabolism and plant physiology [8]; even, since the germination the high concentrations can limit the establishment of productive plots [9]. The quality of underground water in a region is largely determined by the natural process and the anthropogenic activities [10, 11]. Under the shadow of the urbanization and the industrial development, effluents have been lost, and the concentration of heavy metals in the system of underground water has increased [12]. The pollution with heavy metals as the As is potentially a significant problem in all the areas of agricultural activity, the heavy metals can be accumulated above the natural levels on agricultural soil over time because of the continuous application of agrochemicals that content several heavy metals to finally migrate into the underground water [13]. In Mexico and due to natural sources, high concentrations of As have been detected in the aquifers of various areas [14]; in fact, 13 of the 31 states present water pollution by As [15]. The regions with an intense agricultural activity and high geogenic concentrations of As, present a greater risk of pollution as in the case of the Bajío, where the main polluted regions are Acámbaro, Salamanca, Cuerámaro and the Copal in Irapuato with concentrations of $80,180,220$ y $300 \mu \mathrm{g} \mathrm{L}^{-1}$, respectively [15]; it is worth of mention that all these areas belong to the state of Guanajuato. Such As concentrations amply exceed the maximum permissible limit of the Norma Oficial Mexicana NOM-127-SSA1-1994 water for human usage and consumption of $25 \mu \mathrm{g} \mathrm{L}^{-1}$ [16], as well as the maximum level for the agricultural irrigation of $100 \mu \mathrm{g} \mathrm{L}^{-1}$ according to the NOM-CE-CCA-001/89 in most of the cases [17]. The Bajío is widely recognized by its primary production of basic cereals such as the barley which is used in for the brewing industry and as part of this agricultural region, the state of Guanajuato in 2018 produced the $36.4 \%$ of the total whereby the estate is de main barley producer of the country [18]. Despite the above, if the region wants to keep its productive level in the next years will require the constant formation of cultivar of high yield able to grow under conditions of rising concentrations of toxic heavy metal as in the case of As. Given that the germination is the first physiological plant process, the capacity of a seed to germinate under high concentrations of As would be an indicative of some level of tolerance. According to [19], several studies have demonstrated that the first stages of seedling development are very important indicatives to determine the effects of plants toxicity by heavy metals. Once that plants are subjected to factors which generate stress, the plant cells react of different ways depending on the stress source, exposure time, genotype, and the previous periods of exposure [20]. Despite the toxicity of As, different levels of tolerance to this element have evolved in a great number of plant species, mainly through mechanisms of exclusion [21]. The adequate use of the available genetic diversity will always be a viable strategy to form improved lines with higher level of tolerance even to heavy metals as the As. This last according to the advances of [22] with Oryza sativa L.; therefore, it is of vital importance to use the proposed strategy to evaluate the regional cultivars under different levels of plant toxicity and achieve technical recommendations based on scientific evidence. The aim of this study was to evaluate the physiological of barley seedling under AsV toxicity.

\section{Material and Methods}

\section{Plant Material and Treatments}

The experiment was developed in the Laboratorio de Cultivo de Tejidos Vegetales of the Departamento de Agronomía of the Universidad de Guanajuato. As plant material, seeds of Alina and Esperanza barley were used due to these are cultivars haven been widely grown in the Bajío for many years. Because of $\mathrm{AsV}$ is easier assimilated by plants and more common on the agricultural soils [23], the concentrations of 100, 200, 500 and $700 \mathrm{mg} \mathrm{L}^{-1}$ of $\mathrm{AsV}$ were formulated based on sodium arsenate heptahydrate reagent and evaluated as source of experimental variation; as control treatment, distilled water was used. For the germination assays and to obtain seedlings of each cultivar, the seeds were disinfected with $1 \%$ sodium hypochlorite for $5 \mathrm{~min}$ and germinated in humid chambers at $23^{\circ} \mathrm{C}$; 100 seeds were used per assay and $200 \mathrm{~mL}$ of each $\mathrm{AsV}$ concentration.

\section{Variables Evaluated}

Regard the percentage of germination of normal seedlings and the length of the plumules after three and seven days, the indexes $f$ Vigor (VI) and germination (GI) were determined using the formulas purposed by [24]. With the obtained seedling after seven days, the length of the plumules and roots (PL, RL, cm) since the hypocotyl. The seedlings were segmented into plumules and roots to be dehydrated a $90^{\circ} \mathrm{C}$ for $24 \mathrm{~h}$ to determine the total biomass as the corresponding to the plumules and roots (TB, PB, RB, mg), respectively. Regard the biochemical evaluations, the content of proline (PRO, $\mu \mathrm{g} \mathrm{mL}^{-1}$ ) was determined by the method described [25], based on the reaction between such amino acid and the Ninhydrin (2,2-Dihydroxyindane1,3-dione), the determination was performed using $3 \mathrm{~g}$ of fresh tissue and its spectrophotometric measurement at $517 \mathrm{~nm}$. The PRO data was obtained by comparison with a curve of calibration previously performed. The Antioxidant Activity (AA, \%) was determined through the radical 2,2'-Azino-bis (3-ethylbenzothiazoline-6sulfonic acid) (ABTS), using plant extracts prepared following the procedure described by [26], with a modification for the reaction of ABTS with K2S2O8. 
The content of Phenolic Compounds (PC, $\mu \mathrm{g} \mathrm{mL}^{-1}$ of Gallic Acid) was performed using the procedure described by [26], $3 \mathrm{~g}$ of fresh tissue were used to obtain the plant extracts and the reaction was measured at $750 \mathrm{~nm}$ by spectrophotometric [27]. The measurements of AA by ABTS and PC were performed after $7 \mathrm{~min}$ of the beginning of each reaction. The AA was calculated based on the percentage of remaining substrate, while for PC data, it was obtained by comparison with a curve of calibration previously performed. The content

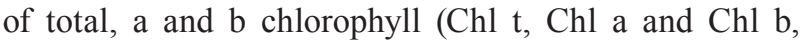
$\mathrm{mg} \mathrm{mL} \mathrm{m}^{-1}$ ) were determined using $1.5 \mathrm{~g}$ of fresh tissue and following the protocol described by [28]. The contents of chlorophyll were calculated with the formulas published by [29] based on the absorbances at 664.1 and $648.6 \mathrm{~nm}$. Considering each cultivar as a block, the data was analyzed in a randomized block design with five repeats and Tukey tests $(0.05)$ were also included; the statistical analysis were performed through the package Pandas 1.0.5 performed with Python 3.8.2. The experimental determinations were complemented with in silico assays to evaluate the uptake of As. Two proteins were considered as possible transporters for such heavy metal: an inorganic phosphorus transporter protein (PHT1) and a heavy metal pump from the P-type ATPase family of pumps (HvHMA1). Such proteins were obtained through a model by homology based on the primary structure due to these proteins have not been crystallized and reported in the literature, the analysis was performed using the SWISS model server [30]. Three main states of oxidation were selected as ligands $\left(\mathrm{As}^{1+}, \mathrm{As}^{3+} \mathrm{y} \mathrm{As}^{5+}\right)$, with the aim to evaluate which of the species have a better affinity for the selected targets. At the same time and based on their physiological importance, endogenous ions of the plant were considered in their main states of oxidation, as $\mathrm{Cu}^{1+}, \mathrm{Cu}^{2+}, \mathrm{Zn}^{1+}, \mathrm{Zn}^{2+}$ y el PO4 $4^{3-}$. The homology models of the proteins were corrected using the software Chimera 1.14 [31]. Finally, molecular couplings between ions and the selected proteins were performed with the computer package Molegro Virtual Docker 5.0 [32].

\section{Results}

The increase in the concentration of $\mathrm{AsV}$ reduced the PL of both cultivars with respect to the control (treatments: $p<0.01$ ). Although the response was similar in both cultivars with an average rate of reduction with 0.85 and $0.83 \mathrm{~cm}$ for each increase in the concentration of AsV for Alina and Esperanza respectively; the PL was always higher for Alina, mainly at the concentration of $700 \mathrm{mg} \mathrm{L}^{-1}$ (blocks: $\mathrm{p}<0.01$ ). The $\mathrm{RL}$ in Alina was reduced $0.5 \mathrm{~cm}$ at the concentration of $100 \mathrm{mg} \mathrm{L}^{-1}$ with respect to the control; while at $700 \mathrm{mg} \mathrm{L}^{-1}$, the response was contrary since the RL increased overcoming the control by $0.6 \mathrm{~cm}$. In the Esperanza cultivar, the response was similar presenting the highest reduction $(2.5 \mathrm{~cm})$ at the concentration of $200 \mathrm{mg} \mathrm{L}^{-1}$ with respect to the control; while at the concentration of $700 \mathrm{mg} \mathrm{L}^{-1}$, the $\mathrm{RL}$ was equal to the found at the control. For this variable, highly significant differences among treatments were found $(\mathrm{p}<0.01)$, but not between cultivars $(\mathrm{p}=0.45)$. The TB was reduced in both cultivars as the concentration of $\mathrm{AsV}$ increased, highly significant differences were found among treatments and between cultivars $(p<0.01)$. The average rates of reduction in Alina and Esperanza were of 12.5 and $16.3 \mathrm{mg}$, respectively. In Alina the higher reduction of the TB (39.5 mg) was found between the concentrations of 100 and $200 \mathrm{mg} \mathrm{L}^{-1}$; while in Esperanza, la higher reduction (55.3 mg) was found between the control and the concentration of $100 \mathrm{mg} \mathrm{L}^{-1}$. Regard the variables of PB and $\mathrm{RB}$, these were also reduced with each increase of the AsV concentration (treatments and blocks: $\mathrm{p}<0.01$ ). In Alina the average rate of reduction for the PB was of $2.4 \mathrm{mg}$ with its highest decrease $(13.4 \mathrm{mg})$ between the control treatment and the concentration of $100 \mathrm{mg} \mathrm{L}^{-1}$; in the case of the root, the average rate of reduction was of $100.1 \mathrm{mg}$ with its highest decrease $(40.8 \mathrm{mg})$ between the concentrations of 100 and $200 \mathrm{mg} \mathrm{L}^{-1}$. In Esperanza, the average rates of reduction were of 7.7 and 8.7 for the plumule and root, respectively. The highest decrease in the PB $(40.8 \mathrm{mg})$ was found between the control and the concentration of $100 \mathrm{mg} \mathrm{L}^{-1}$, while the decrease in the $\mathrm{RB}$ was gradual at each $\mathrm{AsV}$ concentration. Regarding the effects of $\mathrm{AsV}$ on the physiological functions associated with germination. The increase in the concentration of $\mathrm{AsV}$ had a different effect in the germination of both cultivars (blocks: $p<0.01$ ). No significant differences were found in the germination of Alina, due to in this cultivar all treatments were grouped in the same way. But highly significant differences were found in Esperanza (treatments: $p<0.01$ ), with its higher reduction $(2.6 \%)$ between the concentrations 200 and $500 \mathrm{mg} \mathrm{L}^{-1}$. Regard the VI, the same tends were found for both cultivars about a reduction in the vigor as the toxicity level increased (block: $p=0.26$ ). Highly significant differences $(p<0.01)$ were found among the treatments, in Alina the average rate of reduction was of $2.3 \%$ with its higher difference $(4.0 \%)$ between the concentrations of 100 and $200 \mathrm{mg} \mathrm{L}^{-1}$. In Esperanza the average rate of reduction was of $3.9 \%$ with its higher difference $(7.1 \%)$ between the concentrations of 200 and $500 \mathrm{mg} \mathrm{L}^{-1}$. With respect to the biochemical determinations, the PRO in the seedling of both cultivars (blocks: $p=0.99$ ) was reduced as the heavy metal toxicity increased (treatments: $p<0.01$ ). The average rate of reduction in the PRO in Alina was of $1.4 \mu \mathrm{g} \mathrm{mL}^{-1}$ with its higher reduction $\left(4.1 \mu \mathrm{g} \mathrm{mL}^{-1}\right)$ between the concentrations of 100 and $200 \mu \mathrm{g} \mathrm{L}^{-1}$. In the case of Esperanza, the average rate of reduction was of $2.3 \mu \mathrm{g} \mathrm{mL} \mathrm{m}^{-1}$, the higher reduction was of $8.3 \mu \mathrm{g} \mathrm{mL} \mathrm{m}^{-1}$ and found between the control treatment and the concentration of $100 \mathrm{mg} \mathrm{L}^{-1}$. Highly significant differences were found in the inactivation percentage of the radical ABTS among the treatments $(p<0.01)$. 
Table 1. Variables evaluated in seedlings of barley under different concentrations of arsenic V.

\begin{tabular}{|c|c|c|c|c|c|c|c|c|c|c|c|}
\hline Variable & A0 & A100 & A200 & A500 & A700 & E0 & E100 & E200 & E500 & E700 & CV \\
\hline PL** & $12.2 \mathrm{a}$ & $10.6 \mathrm{~b}$ & $9.6 \mathrm{bcd}$ & $9.9 \mathrm{bcd}$ & $8.8 \mathrm{~d}$ & $10.5 \mathrm{bc}$ & $10.2 \mathrm{bc}$ & $9.4 \mathrm{~cd}$ & $9.8 \mathrm{bcd}$ & $7.2 \mathrm{e}$ & 4.7 \\
\hline RL** & $6.0 \mathrm{bc}$ & $5.5 \mathrm{c}$ & $5.8 \mathrm{bc}$ & $6.3 \mathrm{bc}$ & $6.6 \mathrm{ab}$ & $7.2 \mathrm{a}$ & $5.9 \mathrm{bc}$ & $4.7 \mathrm{~d}$ & $5.8 \mathrm{bc}$ & $7.2 \mathrm{a}$ & 5.9 \\
\hline TB** & $319.4 \mathrm{a}$ & $320.7 \mathrm{a}$ & $281.2 \mathrm{ab}$ & $295.9 \mathrm{ab}$ & $269.4 \mathrm{bc}$ & $290.3 \mathrm{bc}$ & $235.0 \mathrm{~cd}$ & $218.0 \mathrm{~cd}$ & $209.8 \mathrm{~d}$ & $225.0 \mathrm{de}$ & 4.5 \\
\hline PB** $^{*}$ & $91.1 \mathrm{~b}$ & $77.7 \mathrm{bc}$ & $79.0 \mathrm{bc}$ & $73.5 \mathrm{bc}$ & $81.4 \mathrm{bc}$ & $120.2 \mathrm{a}$ & $79.4 \mathrm{c}$ & $83.3 \mathrm{bc}$ & $87.4 \mathrm{bc}$ & $89.6 \mathrm{bc}$ & 4.0 \\
\hline RB** & 228.3 & $243.0 \mathrm{a}$ & $202.2 \mathrm{ab}$ & $222.4 \mathrm{a}$ & $188.0 \mathrm{bc}$ & $170.1 \mathrm{~cd}$ & $155.6 \mathrm{~cd}$ & $134.7 \mathrm{~cd}$ & $122.4 \mathrm{~d}$ & $135.4 \mathrm{~cd}$ & 7.0 \\
\hline $\mathrm{GI}^{* *}$ & $6.3 \mathrm{~b}$ & $6.3 \mathrm{~b}$ & $5.7 \mathrm{~b}$ & $5.5 \mathrm{~b}$ & $5.7 \mathrm{~b}$ & $8.6 \mathrm{a}$ & $8.4 \mathrm{a}$ & $8.1 \mathrm{a}$ & $5.5 \mathrm{~b}$ & $5.5 \mathrm{~b}$ & 8.4 \\
\hline $\mathrm{VI}^{* *}$ & $21.4 \mathrm{ab}$ & $17.9 \mathrm{~b}$ & $14.0 \mathrm{c}$ & $13.5 \mathrm{c}$ & $12.1 \mathrm{c}$ & $23.6 \mathrm{a}$ & $21.1 \mathrm{ab}$ & $18.5 \mathrm{~b}$ & $11.4 \mathrm{~cd}$ & $8.1 \mathrm{~d}$ & 10.3 \\
\hline PRO $^{* *}$ & $66.1 \mathrm{ab}$ & $64.0 \mathrm{bc}$ & $59.8 \mathrm{c}$ & $60.9 \mathrm{c}$ & $60.5 \mathrm{c}$ & $69.1 \mathrm{a}$ & $60.8 \mathrm{c}$ & $60.3 \mathrm{c}$ & $61.4 \mathrm{bc}$ & $59.8 \mathrm{c}$ & 3.7 \\
\hline PC** & $389.8 \mathrm{ab}$ & $214.0 \mathrm{ef}$ & $225.2 \mathrm{def}$ & $166.4 \mathrm{f}$ & $186.7 \mathrm{ef}$ & $463.9 \mathrm{a}$ & $367.8 \mathrm{bc}$ & $313.4 \mathrm{~cd}$ & $256.0 \mathrm{def}$ & $283.1 \mathrm{~cd}$ & 12.1 \\
\hline ABTS** & $48.1 \mathrm{f}$ & $71.1 \mathrm{~d}$ & $74.9 \mathrm{~cd}$ & $79.5 \mathrm{~b}$ & $78.2 \mathrm{~b}$ & $71.9 \mathrm{~d}$ & $64.9 \mathrm{e}$ & $61.0 \mathrm{e}$ & $77.7 \mathrm{bc}$ & $89.5 \mathrm{a}$ & 6.1 \\
\hline Chl $a^{* *}$ & $4.2 \mathrm{~d}$ & $4.4 \mathrm{~cd}$ & $3.9 \mathrm{~d}$ & $5.5 \mathrm{ab}$ & $5.9 \mathrm{a}$ & $4.3 \mathrm{~d}$ & $5.0 \mathrm{bc}$ & $5.0 \mathrm{bc}$ & $5.0 \mathrm{bc}$ & $4.2 \mathrm{~d}$ & 4.7 \\
\hline Chl $b^{* *}$ & $2.7 \mathrm{f}$ & $6.7 \mathrm{~cd}$ & $7.9 \mathrm{abc}$ & $9.2 \mathrm{ab}$ & $9.3 \mathrm{a}$ & $4.5 \mathrm{ef}$ & $7.5 \mathrm{bcd}$ & $7.3 \mathrm{~cd}$ & $7.4 \mathrm{~cd}$ & $5.8 \mathrm{de}$ & 5.1 \\
\hline
\end{tabular}

Alina (A), Esperanza (E), concentrations of arsenic V (0, 100, 200, 500 y $\left.700 \mathrm{mg} \mathrm{L}^{-1}\right)$, plumule length (PL, cm), root length (RL, cm), total biomass (TB, mg), plumule biomass ( $\mathrm{PB}, \mathrm{mg}$ ), root biomass ( $\mathrm{RB}, \mathrm{mg})$, germination index (GI), vigor index (VI), proline content (PRO, $\mu \mathrm{g} \mathrm{mL}^{-1}$ ), phenolic compounds content (PC, $\mu \mathrm{g} \mathrm{mL}-1$ of gallic acid), antioxidant activity by ABTC (ABTS, \% of remaining substrate), content of chlorophyll a $\left(\mathrm{Chl} \mathrm{a}, \mathrm{mg} \mathrm{mL}^{-1}\right)$ and $\mathrm{b}\left(\mathrm{Chl} \mathrm{b}, \mathrm{mg} \mathrm{mL}^{-1}\right)$. Values with the same letter within averages rows are statically equal Tukey $(\mathrm{p}<0.05),\left(^{*}\right)$ significant differences $\mathrm{p}<0.05,(* *)$ highly significant differences $\mathrm{p}<0.01$. Coefficient of variation (CV).

In Alina the increase in the concentration of $\mathrm{AsV}$ reduced the $\mathrm{AA}$ in a rate of $7.3 \%$, the higher reduction $(23 \%)$ was identified between the control and the first concentration of $\mathrm{AsV}\left(100 \mathrm{mg} \mathrm{L}^{-1}\right)$. In Esperanza, the AA increased in an average rate of $5.4 \%$ from the control treatment to the concentration of $200 \mathrm{mg} \mathrm{L}^{-1}$ with a later average reduction of $14.2 \%$ under the higher concentrations of $\mathrm{AsV}$. In addition to the determination of AA, highly significant differences were found in the PC between cultivars and among treatments $(\mathrm{p}<0.01)$. In Alina, the PC was less at the control treatment in comparison with all the concentrations of $\mathrm{AsV}$. In the case of Esperanza, the PC was gradually reduced in a rate of $45.2 \mu \mathrm{g} \mathrm{mL}^{-1}$ as the concentration of $\mathrm{AsV}$ increased (Table 1).

For Chl t, a differential response and significant differences were found between cultivars (blocks $\mathrm{p}<0.01$ ), also highly significant differences were found among treatments $(\mathrm{p}<0.01)$. In the case of Alina, Chl $\mathrm{t}$ increased as the concentration of $\mathrm{AsV}$ increased since $6.9 \mathrm{mg} \mathrm{mL}-1$ under the control treatment until $15.2 \mathrm{mg} \mathrm{mL} \mathrm{m}^{-1}$ under the highest concentration of $\mathrm{AsV}$; which indicated that for this cultivar, the content of chlorophyll was reduced under the highest concentrations of $\mathrm{AsV}$, confirming that Alina presents a higher degree of tolerance to the toxicity. In the case of Esperanza, the higher increase in Chl t $\left(3.8 \mathrm{mg} \mathrm{mL}^{-1}\right)$ was identified between the control and the concentration of $100 \mathrm{mg} \mathrm{mL}^{-1}$ of $\mathrm{AsV}$, from such treatment the content of chlorophyll was reduced as the concentration of $\mathrm{AsV}$ increased (Fig. 1).
With respect to the proportions of chlorophylls a (Chl a) and $\mathrm{b}(\mathrm{Chl} \mathrm{b})$, in both cultivars a reduction of the $\mathrm{Chl} \mathrm{a}$ in response to the toxicity was found. In Alina, the $\mathrm{Chl} \mathrm{a}$ and $\mathrm{Chl} \mathrm{b}$ represented the 60.3 and $39.7 \%$ of the Chl t respectively in the control treatment; while under the different concentration of $\mathrm{AsV}$, in average the $\mathrm{Chl} \mathrm{a}$ and $\mathrm{Chl} \mathrm{b}$ represented the $37.2( \pm 1.4)$ and $62.8( \pm 1.4) \%$ of the $\mathrm{Chl} \mathrm{t}$, respectively. In the case of Esperanza, the $\mathrm{Chl}$ a and $\mathrm{Chl} \mathrm{b}$ represented the 48.7 and $51.3 \%$ of the $\mathrm{Chl} \mathrm{t}$ respectively, while under the concentrations of $\mathrm{AsV}$, in average the $\mathrm{Chl}$ a and $\mathrm{Chl} \mathrm{b}$ represented the $40.7( \pm 0.5)$ y $59.3( \pm 0.5) \%$ of the Chl $\mathrm{t}$, respectively. Regarding the uptake of As by the PHT1 and HvHMA1 proteins, the homologous model for PHT1 presented a value of 0.5 GMQE (Global Model Quality Estimation), which indicated a high level of approximation to a real model (Fig. 2a). With respect to the acceptance of the evaluated ions, PHT1 transports $\mathrm{PO}^{3-}$ and presented anion segregation regard the only cation in the evaluated species due to the difference in charges. The coupling energies for the $\mathrm{PO}^{3-}, \mathrm{As}^{1+}, \mathrm{As}^{3+}$, $\mathrm{As}^{5+}, \mathrm{Zn}^{1+}, \mathrm{Zn}^{2+}, \mathrm{Cu}^{1+}$ and $\mathrm{Cu}^{2+}$ ions were -266.93, -91.62, $-199.99,-383.25,-91.62,-133.46,-91.62$ and $-133.4696 \mathrm{~kJ}$ $\mathrm{mol}^{-1}$, respectively; while the electrostatic interactions were $-111.71,-31.38,-244.34,-574.88,-31.38,-91.62$, -31.38 and $-91.62 \mathrm{~kJ}$ mol-1, respectively. Regarding the HvHMAl protein, $\mathrm{Mg}^{2+}$ was considered as the endogenous ion and added as co-factor (Fig. 2b). The coupling energies for the $\mathrm{PO}^{3-}, \mathrm{As}^{1+}, \mathrm{As}^{3+}, \mathrm{As}^{5+}, \mathrm{Zn}^{1+}$, $\mathrm{Zn}^{2+}, \mathrm{Cu}^{1+}$ and $\mathrm{Cu}^{2+}$ ions were $-198.74,-105.85,-315.47$, $-552.28,-105.85,-198.74,-105.85$ and $-198.74 \mathrm{~kJ} \mathrm{~mol}^{-1}$, 


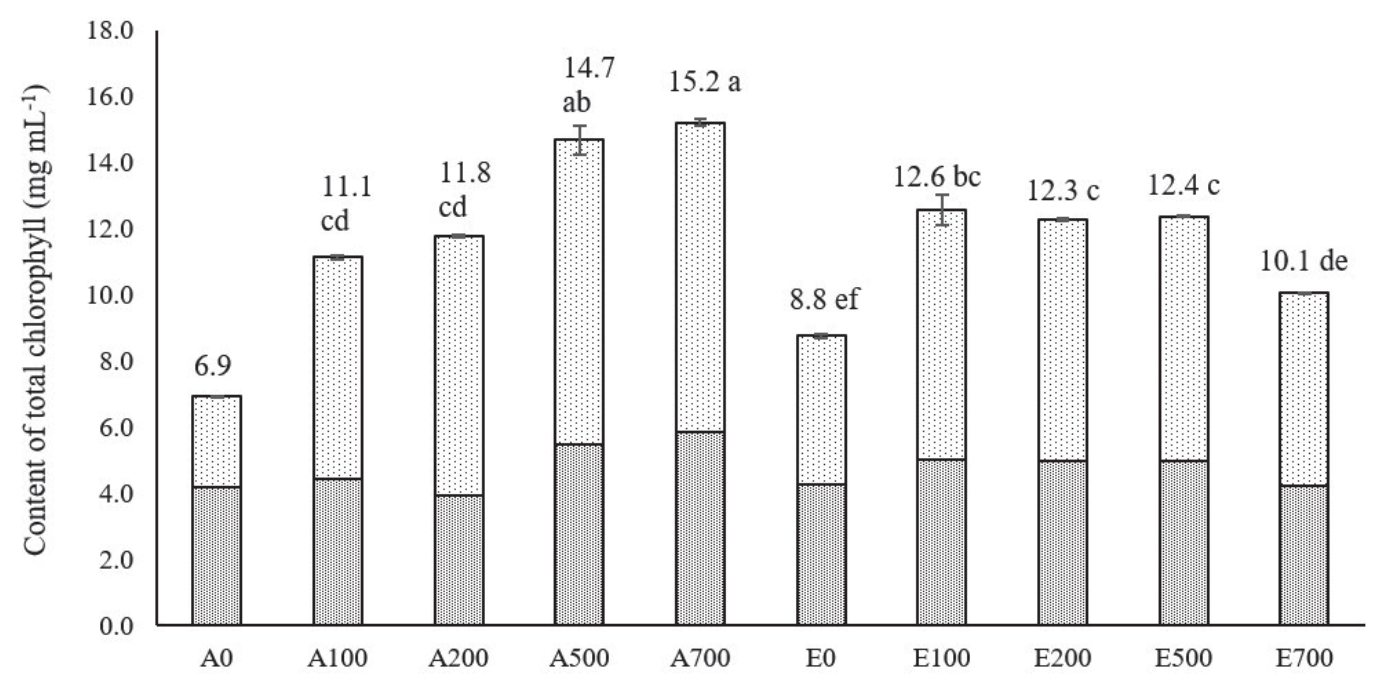

Fig. 1. Content of total chlorophyll $\left(\mathrm{mg} \mathrm{mL}^{-1}\right)$ in seedling of barley under different concentrations of arsenic V. Proportions of chlorophyll a) [0.1 and b) Alina (A), Esperanza (E), concentrations of arsenic V (0, 100, 200, 500 y $\left.700 \mathrm{mg} \mathrm{L}^{-1}\right)$. Values with the same letter within averages rows are statically equal Tukey $(\mathrm{p}<0.05)$.

respectively; while the electrostatic interactions were $243.50,-57.73,-392.45,-653.95,-57.73,-243.50,-57.73$ and $-243.50 \mathrm{~kJ} \mathrm{~mol}^{-1}$, respectively. Finally, it has been reported that the active site for the transporting of heavy metals by HvHMA1 involves the presence of an aspartic acid residue which coincides with our results, due to this site was preferred for the coupling of the studied ions (Fig. 2c).

\section{Discussion of Results}

According to [33], the initial stimulation in the seedling growth of certain cultivars can be attributed to a better absorption of some mineral at low concentrations of AsV. In our experimental results, the growth of the plumules was restricted from the lower concentration of AsV. This indicates that even since the early phenological stages, the $\mathrm{AsV}$ might limit the ability of the seedling to grow as adult plants. Similar reductions in the development of plumules and the leaf area have been reported in both species monocotyledonous as Triticum aestivum [34], Oryza sativa $[35,36]$ and dicotyledonous as Cucumis sativus [37], Lepidium sativum [38], Acacia auriculiformis [39], Helianthus annum [40]. In the case of the root length, significant reductions were found at low AsV concentrations, but in the cultivar Alina the roots a)

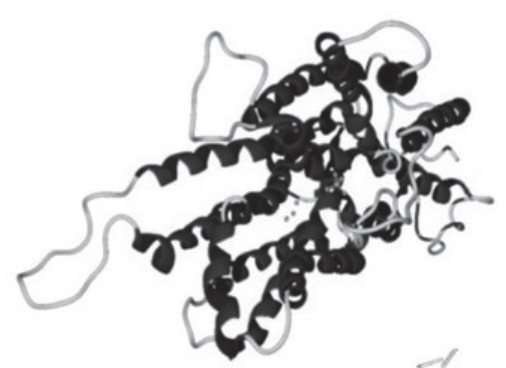

b)

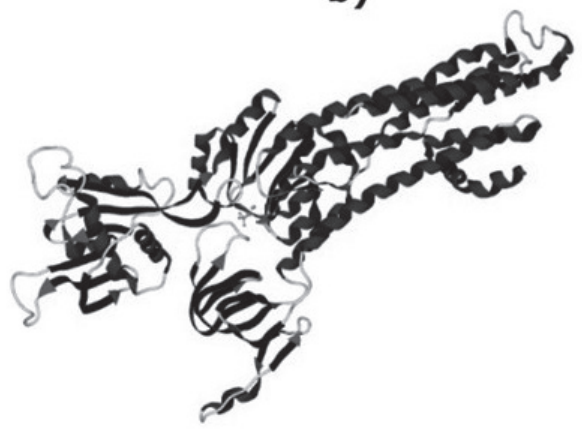

c)

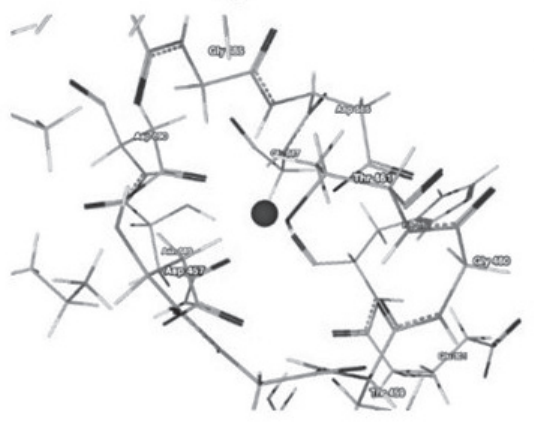

Fig. 2. Homologous models for the evaluated proteins. a) PHT1. b) HvHMA1. c) Active site of HvHMA1. 
elongated at high concentrations. The toxic effect of $\mathrm{AsV}$ in plants is due to its conversion to AsIII by reductase enzymes and expelled to the rhizosphere. AsIII is more soluble and toxic than $\mathrm{AsV}$, because it binds to the sulfhydryl groups of physiologically important enzymes to finally affects their structure and activity [41]. It is important to mention that the presence of arsenic also affects later the populations of microorganisms associated with the rhizosphere [42]. The evidence indicates that based on the level of AsV concentrations, it might be different mechanisms for detoxification in the roots of the seedlings; besides between both cultivars, Alina at high concentrations would also present a higher level of tolerance. A reported mechanism is the complexation of As with ligands and its vacuolar compartimentation such as for the phytochelatins and metallothioneins to convert them to a non-toxic forms [43]. Regard the biomass of seedlings due to the increase of $\mathrm{AsV}$ concentration, this effect has been reported previously for barley [44], as well as for other grasses as wheat [45] and rice [35]. It is worth of mention that according to the experimental results, despite the increase in the concentrations of $\mathrm{AsV}$, the proportions of the plumules and roots biomass as components of the TB were kept practically constant under the different concentrations evaluated. In Alina, the $\mathrm{PB}$ and $\mathrm{RB}$ in average represented the 30 and $70 \%$; while in Esperanza, the average proportions represented the 40 and $60 \%$. With respect to the effect of the AsV on the germination as the first physiological function, the evidence indicated that the germination and vigor of Alina seeds were less affected by the increase in the $\mathrm{AsV}$ concentration. According to [46], increasing the efficiency in the selection for the arsenic tolerance to evaluate the response induced by the arsenic in the genotypes at the germination stage, is particularly important to ensure the establishment and successful growth of productive plots. The results confirmed that it was possible to identify and select cultivars or genotypes with high levels of arsenic tolerance even from early stages and through controlled experiments, such as in the present study. Some studies even recommend the identification of tolerant materials by conducting evaluations under experimental conditions with various sources of stress combined with arsenic [11]. Regard the determination of the proline, the increase of this amino acid in response to the arsenic toxicity as it has been reported in seedlings of other grass species [47]. In our results with barley seedling, the evidence suggests that the differences in the variables evaluated in the present study depended on mechanisms of response mainly mediated by other phytohormones, because no significant increases in the proline concentrations were identified even in the highest concentrations of $\mathrm{AsV}$, despite identifying physiological responses in the seedlings. It is worth of mention that the determination of proline has been used as a biochemical indicator of stress for the toxicity by heavy metals as arsenic; however, in barley we did not identify such response. Regard the antioxidant response, various sources of abiotic stress included the toxicity by arsenic, interrupt the redox homeostasis of the cells and cause the rapid formation of reactive oxygen species that oxidatively damage lipids of the membranes, proteins, nucleic acids, and chlorophylls, leading to an irreparable metabolic dysfunction and finally to cell death [48]. In Alina cultivar, the results suggested that the AA increased in the seedlings as the concentration of $\mathrm{AsV}$ also increased, even this antioxidant response was maintained for the higher evaluated concentration. The PC also presented this same trend in response to the $\mathrm{AsV}$ toxicity. This last indicates that the greater level of tolerance of this cultivar under the highest concentration of $\mathrm{AsV}$ was due to a better antioxidant system. In the case of Esperanza, a high AA levels were identified under the concentrations of 100 and $200 \mathrm{mg} \mathrm{L}^{-1}$, but this response was not maintained under higher concentrations of AsV. As complement of the antioxidant response, in the seedlings of Esperanza the PC content decreased in each concentration of AsV. This last despite the increase found in the AA which indicates that the antioxidant response of this cultivar does not mainly depend on the synthesis of phenolic compounds and probably the incapacity to maintain the synthesis of such compounds could explain the drastic reduction of the AA under high concentrations of AsV. The increase of the oxidant stress and an inadequate cellular response leads to the degradation of the chlorophyll with a subsequent affectation to the photosynthesis $[49,50,51]$. The reduction in the content of chlorophyll in Esperanza was due to a replace of the $\mathrm{Mg}$ central ion by the $\mathrm{AsV}$ or because the inhibition of the chlorophyll synthesis by limiting the corresponding enzymatic activity [52]. The phytotoxicity by heavy metals especially damages the membrane structure and permeability of the chloroplast, as well as causing modifications of inner structure, altering the function of the photosystem II or by interrupting the electron transport chain [51, 53]. In higher plants, the lightharvesting strategy based on pigments as chlorophyll a and $b$ was evidently successful [54]. Chlorophyll b is part of the antenna complexes in the thylakoid membrane, and one of its main function is to transfer the energy captured [55]. Under oxidative stress conditions the chlorophylls a could be quickly degraded [56]. Chlorophyll b is synthesized by the oxidation of a methyl group on the B ring of a tetrapyrrole molecule to a formyl group by chlorophyllide an oxygenase (CAO), the overexpression of $\mathrm{CAO}$ results in the increase of chlorophyll $b$ [57] for this reason, a modification in the ratio of chlorophyll $\mathrm{a} / \mathrm{b}$ might be an important biochemical indicative of tolerance. In our results, the Chl t contents of both cultivars were affected, but the cultivar Alina presented a ratio of chlorophyll $a / b$ with higher content of $\mathrm{Chl} \mathrm{b}$ under the concentration of 500 and $700 \mathrm{mg} \mathrm{L}^{-1}$ which contributed to the higher tolerance level of this cultivar seedlings. Regard the homologous proteins models, for PHT1 which plays a 
key role in the $\mathrm{P}$ absorption in plants due the biochemical soil-rood exchange in their interface [4, 58], the ion that presented the lowest coupling energy was $\mathrm{As}^{5+}$ followed by $\mathrm{PO}^{3-}$, considering that this ion is the endogenous ligand of the protein and the coupling capacity was due to the electrostatic interactions determined. Considering the case in which arsenic was reduced to $\mathrm{As}^{3+}$, this last species also presented a more favorable coupling energy than the other ions, although not lower than $\mathrm{PO}_{4}^{3-}$, whereby in the case of such reduction the phosphate transporting protein would not contribute to the mobilization of arsenic. In this order, the arsenic transport can be promoted by PHT1, due to the ion transporter proteins involve electronic exchange between their moieties and the endogenous substrate by any heavy metal, which commonly presents higher affinity to the ion transport proteins [59]. While for the HvHMA1 protein the results indicated that even though the magnesium is the endogenous substrate, this ion did not have the best coupling energy, being again $\mathrm{As}^{5+}$ the ion that presented the lowest energy for coupling $\left(-132.0 \mathrm{kcal} \mathrm{mol}^{-1}\right) . \mathrm{As}^{3+}$ behaved similarly than for the evaluation with PHT1 because this ion was the second with the highest coupling capacity and likewise, the electrostatic interactions were decisive. Therefore, in the case of being present both species of As, these could be transported due to their high competitiveness with magnesium. Moreover, it has been reported that the active site for the transporting of heavy metals by HvHMA1 involves the presence of an aspartic acid residue [6] which coincides with our results, due to this site was preferred for the coupling of the studied ions (Fig. 2c). Finally, the ion transport process promoted by several kinds of proteins can be blocked by some heavy metals, being the last a higher competitive substrate for the predetermined substrate [60] and perhaps the metabolism process and the rupture of some endogenous molecules promote a different ion transport in some living organisms [61], which can be modeled via computational chemistry.

\section{Conclusions}

The evidence indicated that the seedlings of Alina cultivars presented a higher degree of tolerance to the toxicity in comparison with the cultivar Esperanza, whereby potentially the productive plots of Alina could tolerate higher concentrations of AsV. Despite that the increase in the concentration of the heavy metal reduced the germination and vigor of both cultivars, the seedlings of Alina were less affected because presented a better root growth, antioxidant response and synthesis of chlorophyll b; this last, even under the higher concentrations of AsV. We can also conclude that the AsV could be transported through phosphate transport proteins as PHT1, because this heavy metal species competes with the endogenous ion of phosphorous and the AsIII does not supports in the transporting.
In the case of the protein responsible for transporting heavy metals HvHMA1 can transport both species of arsenic by their competence with the endogenous cation $\mathrm{Mg}^{2+}$.

\section{Conflict of Interest}

The authors deChl are no conflict of interest.

\section{References}

1. GJORGIEVA A.D. Heavy metals and their general toxicity for plants. Plant Science Today, 5 (1), 14, 2018.

2. CHANDRAKAR V., NAITHANI S.C., \& KESHAVKANT S. Arsenic-induced metabolic disturbances and their mitigation mechanisms in crop plants: a review. Biologia, 71 (4), 367, 2016.

3. FERREIRA N.S., OLIVEIRA L.H.B., AGRELLI V., DE OLIVEIRA A.F., NOGUEIRA A.R.A., OLIVEIRA A., GONZALEZ M.H. Bioaccumulation and acute toxicity of $\mathrm{As}(\mathrm{III})$ and $\mathrm{As}(\mathrm{V})$ in Nile tilapia (Oreochromis niloticus). Chemosphere, 217, 349, 2019.

4. BANERJEE A., ROYCHOUDHURY A. Genetic Engineering in Plants for Enhancing Arsenic Tolerance. In Transgenic Plant Technology for Remediation of Toxic Metals and Metalloids. Academic Press: Chennai, India, 463, 2019.

5. NAGAJYOTI P.C., LEE K.D., SREEKANTH T.V.M. Heavy metals, occurrence and toxicity for plants: a review. Environmental Chemistry Letters, 8 (3), 199, 2010.

6. MIKKELSEN M.D., PEDAS P., SCHILLER M., VINCZE E., MILLS R.F., BORG S., MØLLER A., SCHJOERRING J.K., WILLIAMS L.E., BAEKGAARD L., HOLM P.B., PALMGREN M.G. Barley HvHMA1 Is a Heavy Metal Pump Involved in Mobilizing Organellar $\mathrm{Zn}$ and $\mathrm{Cu}$ and Plays a Role in Metal Loading into Grains. PLoS ONE, 7 (11), e49027, 2012

7. SHI G.L., LI D.J., WANG Y.F., LIU C.H., HU Z.B., LOU L.Q., RANGEL Z., CAI Q.S. Accumulation and distribution of arsenic and cadmium in winter wheat (Triticum aestivum L.) at different developmental stages. Science of The Total Environment, 667, 532, 2019.

8. ZHAO F.J., MA J.F., MEHARG A.A., MCGRATH S.P. Arsenic uptake and metabolism in plants. New Phytologist, 181 (4), 777. 2009.

9. GARG N., SINGLA P. Arsenic toxicity in crop plants: physiological effects and tolerance mechanisms. Environmental Chemistry Letters, 9 (3), 303, 2011.

10. DEVIC G., DJORDJEVIC D., SAKAN S. Natural and anthropogenic factors affecting the groundwater quality in Serbia. Science of The Total Environment, 468-469, 933, 2014.

11. BANERJEE A., SAMANTA S., SINGH A., ROYCHOUDHURY A. Deciphering the molecular mechanism behind stimulated co-uptake of arsenic and fluoride from soil, associated toxicity, defence and glyoxalase machineries in arsenic-tolerant rice. Journal of Hazardous Materials, 390, 121978, 2020.

12. PAPAIOANNOU A., DOVRIKI E., RIGAS N., PLAGERAS P., RIGAS I., KOKKORA M., PAPASTERGIOU P. Assessment and Modelling of Groundwater Quality Data by Environmetric Methods 
in the Context of Public Health. Water Resources Management, 24 (12), 3257, 2010.

13. WONGSASULUK P., CHOTPANTARAT S., SIRIWONG W., ROBSON M. Heavy metal contamination and human health risk assessment in drinking water from shallow groundwater wells in an agricultural area in Ubon Ratchathani province, Thailand. Environmental Geochemistry and Health, 36 (1), 169, 2014.

14. ARMIENTA, M. A., \& SEGOVIA, N. Arsenic and fluoride in the groundwater of Mexico. Environmental Geochemistry and Health, 30 (4), 345, 2008.

15. BUNDSCHUH J., LITTER M. I., PARVEZ F., ROMÁNROSS G., NICOLLI H. B., JEAN J.S., LI C.W., LÓPEZ D., ARMIENTA M.A., GUILHERME L. R.G., GÓMEZ A., CORNEJO L., CUMBAL L., TOUJAGUEZ, R. One century of arsenic exposure in Latin America: A review of history and occurrence from 14 countries. Science of The Total Environment, 429, 2, 2012.

16. SECRETARIA DE SALUD. Salud ambiental, agua para uso y consumo humano-límites permisibles de calidad y tratamientos a que debe someterse el agua para su potabilización, MÉXICO: DOF, 1994. Retrieved from http://www.salud.gob.mx/unidades/cdi/nom/127ssa14.html

17. ECOLOGÍA S., DE DESARROLLO U.Y. Acuerdo por el que se establecen los criterios ecológicos de calidad del agua CE-CCA-001/89 México: DOF, 1989. Retrieved from http://legismex.mty.itesm.mx/acu/acca001.pdf

18. SIAP. Producción Agropecuaria y Pesquera. Sistema de Información Agroalimentaria y Pesquera. Secretaria de Agricultura y Desarrollo Rural, 2020.

19. AKINCI, IRFAN ERSIN S.A. Effect of chromium toxicity on germination and early seedling growth in melon (Cucumis melo L.). African Journal of Biotechnology, 9 (29), 4589, 2010

20. MØLLER I.M., JENSEN P.E., HANSSON A. Oxidative Modifications to Cellular Components in Plants. Annual Review of Plant Biology, 58 (1), 459, 2007.

21. VERBRUGGEN N., HERMANS C., SCHAT H. Mechanisms to cope with arsenic or cadmium excess in plants. Current Opinion in Plant Biology, 12 (3), 364, 2009.

22. KURAMATA M., ABE T., KAWASAKI A., EBANA K., SHIBAYA T., YANO M., ISHIKAWA S. Genetic diversity of arsenic accumulation in rice and QTL analysis of methylated arsenic in rice grains. Rice, 6 (1), 3, 2013.

23. ISAYENKOV S.V., MAATHUIS F.J.M. The Arabidopsis thaliana aquaglyceroporin AtNIP7;1 is a pathway for arsenite uptake. FEBS Letters, 582 (11), 1625, 2008.

24. LI C., FENG S., SHAO Y., JIANG L., LU X., HOU X. Effects of arsenic on seed germination and physiological activities of wheat seedlings. Journal of Environmental Sciences, 19 (6), 725, 2007.

25. BATES L.S., WALDREN R.P., TEARE I.D. Rapid determination of free proline for water-stress studies. Plant and Soil, 39 (1), 205, 1973.

26. MARTÍNEZ-CRUZ O., PAREDES-LÓPEZ O. Phytochemical profile and nutraceutical potential of chia seeds (Salvia hispanica L.) by ultra high performance liquid chromatography. Journal of Chromatography A, 1346, 43, 2014.

27. AWAD M.A., AL-QURASHI A.D., MOHAMED S.A. Antioxidant capacity, antioxidant compounds and antioxidant enzyme activities in five date cultivars during development and ripening. Scientia Horticulturae, 129 (4), 688, 2011.
28. DUDEK G., STRZELEWICZ A., KRASOWSKA M., RYBAK A., TURCZYN R. A spectrophotometric method for plant pigments determination and herbs Chl assification. Chemical Papers, 68 (5). 2014.

29. LICHTENTHALER H.K., BUSCHMANN C. Chlorophylls and Carotenoids: Measurement and Characterization by UV-VIS Spectroscopy. Current Protocols in Food Analytical Chemistry, 1 (1), F4.3.1, 2001.

30. WATERHOUSE A., BERTONI M., BIENERT S., STUDER G., TAURIELLO G., GUMIENNY R., HEER F.T., DE BEER T.A.P., REMPFER C., BORDOLI R.L., SCHWEDE T. SWISS-MODEL: homology modelling of protein structures and complexes. Nucleic Acids Research, 46 (W1), W296. 2018.

31. PETTERSEN E.F., GODDARD T.D., HUANG C.C., COUCH G.S., GREENBLATT D.M., MENG E.C., \& FERRIN T.E. UCSF Chimera? A visualization system for exploratory research and analysis. Journal of Computational Chemistry, 25 (13), 1605, 2004.

32. THOMSEN R., CHRISTENSEN M.H. MolDock: A New Technique for High-Accuracy Molecular Docking. Journal of Medicinal Chemistry, 49 (11), 3315, 2006.

33. SHIWACH E., KUMAR S. Phytotoxicity of Arsenic Compound on Hordeum vulgare (L.) Seedlings. International Journal Engineering and Management Research, 6 (4), 477, 2016.

34. SHOAIB S.A. AND SHOAIB A. Toxic effect of arsenate on germination, early growth and bioaccumulation in wheat (Triticum aestivum L.). Pakistan Journal of Agricultural Sciences, 51 (2), 389, 2014.

35. THOUNAOJAM T.C., MEETEI T.T., PANDA S.K., \& UPADHYAYA H. North East India Rice Genotypes: Screening of Arsenic Tolerant and Sensitive Rice at Germinating Stage. Journal of Stress Physiology \& Biochemistry, 15 (4), 68, 2019.

36. ASGHER M., AHMED S., SEHAR Z., GAUTAM H., GANDHI S.G., KHAN N.A. Hydrogen peroxide modulates activity and expression of antioxidant enzymes and protects photosynthetic activity from arsenic damage in rice (Oryza sativa L.). Journal of Hazardous Materials, 401, 123365, 2021.

37. KHAN B.M., AFRIN A.H., HOSSAIN M.M. Effects of phosphorus on germination and seedling growth of Cucumis sativus L. in arsenic solution culture. International journal of Rural Development, Environment and Health Research, 2 (1), 48, 2018.

38. NOURI M., HADDIOUI A. Improving seed germination and seedling growth of Lepidium sativum with different priming methods under arsenic stress. Acta Ecologica Sinica, 41 (1), 64, 2021.

39. SOFEA A., ZERKOUT A., AZWADY A., RUSEA G., MUSKHAZLI M. Assessment of Acacia auriculiformis Cunn. Ex Benth. Seed Germination and Growth Resistance towards Arsenic Toxicity. Annual Research \& Review in Biology, 18 (1), 1, 2017.

40. MUHAMMAD A.I., MUHAMMAD N.C., RASS M.K., ZULFIQAR A., TARIQ M. Toxicity of arsenic (As) on seed germination of sunflower (Helianthus annuus L.). International Journal of Physical Sciences, 8 (17), 840, 2013.

41. FAROOQ M.A., ISLAM F., ALI B., NAJEEB U., MAO B., GILL R.A., YAN G., SIDDIQUE K.H.M., ZHOU W. Arsenic toxicity in plants: Cellular and molecular mechanisms of its transport and metabolism. Environmental and Experimental Botany, 132, 42, 2016. 
42. JIA Y., HUANG H., CHEN Z., ZHU Y.-G. Arsenic Uptake by Rice Is Influenced by Microbe-Mediated Arsenic Redox Changes in the Rhizosphere. Environmental Science \& Technology, 48 (2), 1001, 2014.

43. ABBAS G., MURTAZA B., BIBI I., SHAHID M., NIAZI N.K., KHAN M.I., HUSSAIN M. Arsenic Uptake, Toxicity, Detoxification, and Speciation in Plants: Physiological, Biochemical, and Molecular Aspects. International Journal of Environmental Research and Public Health, 15 (1), 1:45, 2018.

44. SANAL F., ŞEREN G., GÜNER U. Effects of Arsenate and Arsenite on Germination and Some Physiological Attributes of Barley Hordeum vulgare L. Bulletin of Environmental Contamination and Toxicology, 92 (4), 483. 2014.

45. ZENGIN F. Effects of exogenous salicylic acid on growth characteristics and biochemical content of wheat seeds under arsenic stress. Journal of Environmental Biology, 36 (1), 249, 2015.

46. TALUKDAR D. Effect of arsenic-induced toxicity on morphological traits of Trigonella foenum-graecum L. and Lathyrus sativus L. during germination and early seedling growth. Current Research Journal of Biological Sciences, 3 (2), 116, 2011.

47. HASANUZZAMAN M., \& FUJITA M. Exogenous sodium nitroprusside alleviates arsenic-induced oxidative stress in wheat (Triticum aestivum L.) seedlings by enhancing antioxidant defense and glyoxalase system. Ecotoxicology, 22 (3), 584, 2013.

48. MISHRA S., JHA A.B., DUBEY R.S. Arsenite treatment induces oxidative stress, upregulates antioxidant system, and causes phytochelatin synthesis in rice seedlings. Protoplasma, 248 (3), 565, 2011.

49. PENG Y.Y., LIAO L.L., LIU S., NIE M.M., LI J., ZHANG L.D., CHEN Z.C. Magnesium Deficiency Triggers SGRMediated Chlorophyll Degradation for Magnesium Remobilization. Plant Physiology, 181 (1), 262, 2019.

50. FAN Z., TAN X.-L., CHEN J., LIU Z., KUANG J., LU W., SHAN W., CHEN J. BrNAC055, a Novel Transcriptional Activator, Regulates Leaf Senescence in Chinese Flowering Cabbage by Modulating Reactive Oxygen Species Production and Chlorophyll Degradation. Journal of Agricultural and Food Chemistry, 66 (36), 9399, 2018.

51. ANJUM S.A., TANVEER M., HUSSAIN S., ASHRAF U., KHAN I., WANG L. Alteration in Growth, Leaf Gas Exchange, and Photosynthetic Pigments of Maize Plants Under Combined Cadmium and Arsenic Stress. Water, Air, \& Soil Pollution, 228 (1), 13, 2017.

52. YILMAZ D.D., TEMIZGÜL A. Assessment of Arsenic and Selenium Concentration with Chlorophyll Contents of Sugar Beet (Beta vulgaris var.saccharifera) and Wheat (Triticum aestivum) Exposed to Municipal Sewage Sludge Doses. Water, Air, \& Soil Pollution, 223 (6), 3057, 2012.

53. SGHAIER D.B., DUARTE B., BANKAJI I., CAÇADOR I., SLEIMI N. Growth, chlorophyll fluorescence and mineral nutrition in the halophyte Tamarix gallica cultivated in combined stress conditions: Arsenic and $\mathrm{NaCl}$. Journal of Photochemistry and Photobiology B: Biology, 149, 204, 2015.

54. LARKUM A.W.D., RITCHIE R.J., RAVEN J.A. Living off the Sun: chlorophylls, bacteriochlorophylls and rhodopsins. Photosynthetica, 56 (1), 11, 2018.

55. JAHNS P., HOLZWARTH A.R. The role of the xanthophyll cycle and of lutein in photoprotection of photosystem II. Biochimica et Biophysica Acta (BBA) - Bioenergetics, 1817 (1), 182, 2012.

56. LEE E., AHN H., CHOE E. Effects of light and lipids on chlorophyll degradation. Food Science and Biotechnology 23 (4), 1061, 2014.

57. TANAKA A., TANAKA R. The biochemistry, physiology, and evolution of the chlorophyll cycle. Advances in Botanical Research, 90, 183, 2019.

58. SCHÜNMANN P.H.D., RICHARDSON A.E., VICKERS C.E., DELHAIZE E. Promoter Analysis of the Barley Pht1; 1 Phosphate Transporter Gene Identifies Regions Controlling Root Expression and Responsiveness to Phosphate Deprivation. Plant Physiology, 136 (4), 4205, 2004.

59. VILLASEÑOR-GRANADOS T., DÍAZ-CERVANTES E., SOTO-ARREDONDO K.J., MARTÍNEZ-ALFARO M., ROBLES J., GARCÍA-REVILLA M.A. Binding of $\mathrm{Pb}-$ Melatonin and $\mathrm{Pb}$-(Melatonin-metabolites) complexes with DMT1 and ZIP8: implications for lead detoxification. DARU Journal of Pharmaceutical Sciences, 27 (1), 137, 2019.

60. SOTO-ARREDONDO K.J., ROBLES J., DÍAZCERVANTES E., RUIZ-RAMÍREZ C., GARCÍAREVILLA M.A., WROBEL K., DÍAZ-MUÑOZ M., MÉNDEZ I., FLORES A., ACEVEDO-AGUILAR F.J., MARTÍNEZ-ALFARO M. Effects of lead and leadmelatonin exposure on protein and gene expression of metal transporters, proteins and the copper/zinc ratio in rats. BioMetals, 31 (5), 859, 2018.

61. DÍAZ-CERVANTES E., GARCÍA-REVILLA M.A., SOTO-ARREDONDO K., VILLASEÑOR-GRANADOS T., MARTÍNEZ-ALFARO M., \& ROBLES J. Computational study of metal complexes formed with EDTA, melatonin, and its main metabolites: implications in lead intoxication and clues to a plausible alternative treatment. Journal of Molecular Modeling, 25 (1), 18, 2019. 